\title{
A Note on the Translations
}

When an English translation of a German text has been altered, a reference to the German original is included in addition to the English reference.

\section{A Note on Terminology}

In the text the word "historico-philosophical"-from the German "geschichtsphilosophisch"-appears frequently. In German this term has a very specific meaning which might not be readily apparent to the unsuspecting English-speaking reader: it means from the standpoint or perspective of a given philosophy of history. It thus represents the adjectival form of the term "philosophy of history," for which there is no satisfactory English equivalent. 